\title{
Irrigation Water Chemistry: Impact on Microbial Community Composition and Biogeochemical Leaching under Perennial Ryegrass (Lolium perenne $[\mathbf{L}]$ )
}

\author{
Leon C. Holgate, Jacqueline A. Aitkenhead-Peterson, and Terry J. Gentry \\ Department of Soil and Crop Sciences, Texas A\&M University, 2474 TAMU College Station, TX 77843, USA \\ Correspondence should be addressed to Jacqueline A. Aitkenhead-Peterson, jpeterson@ag.tamu.edu
}

Received 13 January 2011; Accepted 24 February 2011

Academic Editors: P. Rautio and T. Sime-Ngando

Copyright $\odot 2011$ Leon C. Holgate et al. This is an open access article distributed under the Creative Commons Attribution License, which permits unrestricted use, distribution, and reproduction in any medium, provided the original work is properly cited.

\begin{abstract}
Greywater recycling and rain water harvesting for irrigating urban and suburban landscapes may reduce the use of potable water in arid and subtropical climates but affect soil microbial community composition and biogeochemical cycling. Municipal tap water, greywater, and harvested rain water were used to irrigate (Lolium perenne L.) planted in a constructed soil over a 20 week period. Irrigation with grey water significantly increased the relative abundance of gram-positive biomarkers ANTEISO $15: 0$, ISO $17: 1 \mathrm{G}$, gram-negative biomarkers 19:0 CYCLO c11-12 and bacterial biomarker 18:0 $(P<.05)$ relative to irrigation with harvested rain water. Significant decreases were observed in the relative abundance of gram-positive biomarker 16:0, gram-negative biomarker $16: 1 \omega 7 \mathrm{c}$, both fungi biomarkers $(18: 2 \omega 6 \mathrm{c}$ and $18: 1 \omega 9 \mathrm{c})$ in soils irrigated with greywater $(P<.05)$. Dissolved organic carbon losses from soil were a significant two-to-four times greater from soils irrigated with municipal tap water and greywater relative to soils irrigated with harvested rain water $(P<.001)$. This study highlights the effect that municipal tap water and grey water may have on microbial community composition and soil nutrient dynamics under irrigated turf grass.
\end{abstract}

\section{Introduction}

Research examining irrigation water chemistry and its affect on microbial community composition and nutrient leaching in soils under rapidly expanding turfgrass regions in southern states of the USA is necessary when advising on management strategies for water reuse. Irrigation of turfgrass, particularly with municipal tap water (MTW) high in sodium and bicarbonate may result in leaching of dissolved organic carbon (DOC) and orthophosphate-P from the planted soil to surface waters $[1,2]$ and further compromise evapotranspiration at the plot scale [3]. Several studies have examined the chemistry of irrigation water particularly in agroecosystems, where the focus has been on plant health and crop yields $[4,5]$, and the effect of wastewater effluent on soil nutrient dynamics in agricultural and urban ecosystems [6-8]. Fewer studies have investigated the affect of grey water and harvested rain water on soil dissolved organic carbon and nitrogen leaching and soil microbial community composition under turfgrass [9].
Climate-related differences in outdoor water use are illustrated by annual residential use of municipal tap water in the humid temperate state of Wisconsin compared to the arid state of Nevada at 208.4 and $784.5 \mathrm{~L} \mathrm{person}^{-1} \mathrm{~d}^{-1}$, respectively [10]. Landscape water use across the United States averages between $40 \%$ and $70 \%$ of residential water use [11] with the higher percentages of municipal water use being outdoors in more arid states. Due to increasing demands on available water supplies, efficient water use for irrigation in urban environments will have to become part of long-term public strategies for conserving this natural resource [12].

Greywater may provide one option for irrigating turfgrass or landscape plants in urban open spaces and suburban gardens in the southern regions of the USA. Grey water is derived from residential uses such as showers, laundering, and bathing [13]. Grey water can, however, vary significantly in composition [14], and as a result of this different chemical and biological composition, there have been some concerns about the effect of its use on the soil environment. 
Metals such as $\mathrm{Ni}, \mathrm{Zn}, \mathrm{Cu}$, and $\mathrm{Cd}$ which are typically found in waste water effluent have been shown to alter microbial community composition in heavy metal polluted soils in Poland [15]. Greywater composition is dependent however on several factors; these include the number and age of household occupants, types of greywater storage and the source of grey water [16]. The microbial quality of greywater and its total nitrogen and phosphorus content are also important factors to consider [14]. Depending upon the source of greywater, there is also the potential presence of fecal indicator organisms (e.g., E. coli) and pathogens [17].

Rainwater harvesting may also serve as an alternative solution to increase water availability for irrigation in urban areas. Harvesting of rain water has been a common practice in many nations around the world for thousands of years, especially in arid or remote areas, where the provision of water through piped networks is uneconomic or not technically feasible [18]. Even though such a solution seems attractive from an ecological point of view, the potential health risks of harvested rainwater related to microbiological and chemical contaminants should be taken into account. For example, Chang et al. [19] examined the run off quality for four commonly used roofing materials and suggested that roof run off could be a potential source of nonpoint pollution due to compounds such as heavy metals contained in (1) roofing materials that may be leached into run off, (2) airborne pollutants, and (3) organic substances, such as leaves, dead insects, and bird waste, which are added to roofs by interception and deposition. Chemical contamination of rainwater can also occur due to traffic emissions and industrial pollution in urban areas or due to agricultural usage of fertilizers and pesticides in rural areas [18].

The major objectives of this study were (1) to investigate the impact of four different irrigation water types: (a) municipal tap water, (b) harvested rain water, (c) washing machine water, and (d) harvested bath water on nutrient leaching under irrigated perennial ryegrass (Lolium perenne L.), (2) the impact of a starter fertilizer on leachate chemistry, and (3) to examine the influence of the different irrigation source water on soil microbial community composition.

\section{Materials and Methods}

2.1. Experimental Design. Urban soils by their nature are considered "constructed soils" and our microcosm experiment was designed to mimic depths of sand and sod typically used when laying turfgrass in urban subdivisions. The experiment consisted of four water-treatments: (1) municipal tap water (MTW), (2) harvested rain water (HRW), (3) bath water (GWB), and (4) washing machine water (GWW). One grass species was examined; perennial ryegrass (Lolium perenne L.) with six replicates per irrigation treatment of which three were fertilized and three were unfertilized. Each treatment microcosm (plastic plant pot $20 \mathrm{~cm}$ diameter and $17.5 \mathrm{~cm}$ depth) comprised peagravel at a bulk density of $1.3 \mathrm{~g} \cdot \mathrm{cm}^{-3}$ and a depth of approximately $2 \mathrm{~cm}$ for drainage, a commercial grade, medium sand at a bulk density of $1.3 \mathrm{~g} \cdot \mathrm{cm}^{-3}$, and depth of $9 \mathrm{~cm}$ covered by a turfgrass sod layer prepared prior to the experiment in seed trays.
To prepare the turfgrass sodlayer, fourteen seed trays $(\mathrm{L} 50 \mathrm{~cm} \times \mathrm{W} 26 \mathrm{~cm} \times \mathrm{D} 6 \mathrm{~cm})$ were filled with a sandy top soil at a bulk density of $1.3 \mathrm{~g} \cdot \mathrm{cm}^{-3}$. Perennial ryegrass seeds were added to the topsoil in twelve of the seed trays at a pure live seed (PLS) rate of 11 seedlings per square inch which was estimated at $7 \mathrm{~g}$ seeds per each tray. Six of the seed trays received a starter fertilizer (Scotts Starter Brand, Marysville, Ohio; $10 \mathrm{~N}-27 \mathrm{P}_{2} \mathrm{O}_{5}-5 \mathrm{~K}_{2} \mathrm{O}$ ) at a rate of $2.5 \mathrm{~g}$ for each tray which is equivalent to $8.1 \mathrm{~kg}$ per $464.5 \mathrm{~m}^{2}$, and the other six trays did not receive any fertilizer. Two additional seed trays with topsoil were used as blanks (i.e., contained no grass seeds), one of which received a starter fertilizer and one did not. The seed trays were irrigated with municipal tap water until the ryegrass had reached a height of 5-7.5 cm (approximately 4 weeks). Municipal tap water was used for initial irrigation prior to commencement of our irrigation treatments, because we assumed that a typical sod farm used either municipal tap or well water for irrigating turfgrass during establishment. After 4 weeks, the sod layer grown in the seed trays was cut into sections and added to the top of the soil microcosm units. Grasses were clipped approximately biweekly, weights were recorded and the clippings returned to pots.

2.2. Irrigation Water Supply and Chemistry. Rainwater was harvested throughout the spring of 2008 and stored at room temperature in a $170 \mathrm{~L}$ plastic drum and aerated with an aquarium air pump. The drum was covered with aluminum foil to block light and placed in a dark room to prevent algal growth. Rain water was collected from the $170 \mathrm{~L}$ drum monthly into a $26 \mathrm{~L}$ bottle and stored in the greenhouse. Grey water was collected from a residential household of two adults and two children under the age of two years old. Bath and washing machine grey water were collected fresh every month in $26 \mathrm{~L}$ bottles and stored in the greenhouse. All bottles were aerated with aquarium air pumps. Subsamples for Escherichia coli (E. coli) analyses were collected from every new batch of grey water.

Irrigation water was supplied to each treatment pot at an average flow rate of $2.5 \mathrm{~mL} \mathrm{~s}^{-1}$. The pots were irrigated every two or three days with $150 \mathrm{~mL}$ of their respective irrigation treatment to ensure they did not dry out thoroughly and maintained adequate moisture. A thorough leaching was done once-weekly by adding $300 \mathrm{~mL}$ to the pots. Leachate was collected from each pot in $500 \mathrm{~mL}$ sterile Whirl-Pak bags and transported to the laboratory on ice for filtration and analysis. The treatments continued for five months (20 weeks). Municipal tap water from College Station, Texas, was obtained from a faucet in the greenhouse and used for watering following the same protocol as the other treatments. Prior to each leaching, a sample of each irrigation water type was collected for chemical analysis so that input chemistry for each constituent could be quantified and also because during storage the chemistry of the irrigation water might change. The average (mean) and standard deviation $(n=$ 20 weeks) for each chemical constituent for each of the irrigation waters used in this experiment was calculated (Table 1). 
2.3. Microbial Community Composition. At the end of the experimentation period, topsoil layers were sampled from each microcosm and differences in microbial community composition were determined using whole-soil fatty acid methyl ester analysis (FAME). Analysis of whole-soil FAME profiles were used in order to detect changes in microbial communities in the different irrigation treatments based on the lipid composition of microbial membranes [20]. Extraction of lipids and saponification were performed by adding $15 \mathrm{~mL}$ of $0.2 \mathrm{M} \mathrm{KOH}$ dissolved in methanol to the samples and heating at $37^{\circ} \mathrm{C}$ for $1 \mathrm{~h}$. Samples were vortexed for $20 \mathrm{~s}$ every $20 \mathrm{~min}$. Extraction mixtures were neutralized with glacial acetic acid, and then $3 \mathrm{~mL}$ of hexane was added to each sample which was vortexed for $10 \mathrm{~s}$. Extracts were centrifuged at $1000 \times \mathrm{g}$-force, at $4^{\circ} \mathrm{C}$ for $20 \mathrm{~min}$, and the organic phase was separated with a Pasteur pipette into a clean, ashed glass tube. Hexane was evaporated almost to dryness under nitrogen gas and then transferred to labeled vials which were stored at $-20^{\circ} \mathrm{C}$. An Agilent model 6890 gas chromatograph with flame ionization detector (Agilent, Wilmington, DE, USA) was used to quantify lipids and fatty acids. Briefly, $2 \mu \mathrm{L}$ of each sample were injected into a Hewlett Packard (Agilent) Ultra 2 (Crosslinked 5\% Phenyl methyl silicone) column $25 \mathrm{~m} \times 0.20 \mathrm{~mm} \times 0.33 \mu \mathrm{m}$ with a $100: 1$ split ratio and flow rate of $0.6 \mathrm{~mL} \mathrm{~min}^{-1}$ using hydrogen as the carrier gas. The injection temperature was $250^{\circ} \mathrm{C}$, and the detection temperature was $300^{\circ} \mathrm{C}$. The initial oven temperature was $170^{\circ} \mathrm{C}$ and was ramped at $5^{\circ} \mathrm{C} \mathrm{min}^{-1}$ to a final temperature of $300^{\circ} \mathrm{C}$, for a total run time of $12.0 \mathrm{~min}$. Peaks were named using the Sherlock Eukary program (MIDI, Inc., Newark, DE, USA). The fatty acids present can give an indication of the gramnegative, gram-positive, fungi, and protozoa present in the sample.

2.4. Leachate Collection and Analyses. The $\mathrm{pH}$ and conductivity of each leachate sample was recorded on each sample prior to filtration. Solutions were filtered using ashed $\left(500^{\circ} \mathrm{C}\right.$ for 4 hours) Whatman GF/F filters (nominal pore size $0.7 \mu \mathrm{m}$ ) and frozen until analysis. Dissolved organic carbon (DOC) and total dissolved nitrogen (TDN) were measured with high temperature platinum-catalyzed combustion using a Shimadzu TOC- $\mathrm{V}_{\mathrm{CSH}}$ and Shimadzu total measuring unit (TNM-1) (Shimadzu Corp, Houston, TX, USA). Dissolved organic carbon was quantified as nonpurgeable carbon using USEPA method 415.1 which entailed acidifying $(2 \mathrm{~N} \mathrm{HCl})$ the sample and sparging for $4 \mathrm{~min}$ with $\mathrm{C}$-free air. Ammonium$\mathrm{N}$ was analyzed using the phenate hypochlorite method with sodium nitroprusside enhancement (USEPA method 350.1), and nitrate- $\mathrm{N}$ was analyzed using $\mathrm{Cd}-\mathrm{Cu}$ reduction (USEPA method 353.3). Colorimetric methods were performed with a Westco Scientific Smartchem Discrete Analyzer (Westco Scientific Instruments Inc. Brookfield, CT, USA). Dissolved organic nitrogen $(\mathrm{DON})$ was calculated as the product of $\mathrm{TDN}-\left(\mathrm{NH}_{4}-\mathrm{N}+\mathrm{NO}_{3}-\mathrm{N}\right)$. Water blanks, replicate samples, NIST traceable, and check standards were run every 12th sample to monitor instrument precision. Coefficients of variance of replicates were less than $5 \%$ for TDN and DOC and less than $2 \%$ for the colorimetric methods during each analytical run otherwise the samples were reanalyzed.

2.5. Quantification of Escherichia coli. The use of grey water supply for irrigation of turfgrass has implications of introducing E. coli into the environment which may potentially run off to surface waters. Each new batch of input bath and washing machine water was analyzed for E. coli using a modified mTEC agar and the membrane filtration technique (USEPA method 1603). Briefly, irrigation water or leachate samples were filtered through a sterile $0.45 \mu \mathrm{m}$ Millipore filter and incubated on modified mTEC agar for $2 \mathrm{hr}$ at $35^{\circ} \mathrm{C}$ then for $22-24 \mathrm{hr}$ at $44.5^{\circ} \mathrm{C}$. If $E$. coli counts in irrigation water sources exceeded 1000 colony-forming units (CFUs) $/ 100 \mathrm{~mL}$, then the leachate from the treatment pots irrigated with that water were also analyzed for E. coli.

2.6. Statistical Analysis. Leachate concentration data were calculated to a mass of nutrient ( $\mathrm{mg} \mathrm{kg} \mathrm{dry} \mathrm{soil}{ }^{-1}$ ) value to normalize the data, because volumes of leachate differed among treatments and by season.

Univariate analysis of variance with two factors was applied to the leachate and FAME data to determine if there was a significant effect of fertilization, irrigation, or an interaction between fertilization and irrigation. Because there was no statistically significant effect of fertilizer on DOC and DON loss to leachate, we applied one-way analysis of variance (ANOVA) with a post hoc Tukey HSD test combining fertilized and unfertilized treatments $(n=6$ per irrigation treatment) on all our chemistries.

Mean and standard deviation was calculated for each of the FAME biomarkers. One way analysis of variance with post hoc Tukey HSD was applied to the data $(n=$ 6 for each irrigation treatment). To determine if there was a difference in microbial community composition, we used cluster analyses and Euclidean distance to determine if the assemblages of FAME biomarkers were similar or dissimilar for our irrigation treatments. SPSS v.16 was used for statistical analyses.

\section{Results}

3.1. Soil Microbial Community Composition. A total of seventeen fatty acids were recognized of which fourteen were determined to be of bacterial origin, two of fungal and one protozoan origin. Highest relative abundances were observed for gram-positive in biomarker 16:0 and highest gramnegative were found in biomarker $16: 1 \omega 5 \mathrm{c}$ (Table 2). The abundance of fungi biomarkers $18: 2 \omega 6 \mathrm{c}$ and $18: 1 \omega 9 \mathrm{c}$ was significantly higher in the harvested rain water-treatments (Table 2). Bacteria 18:0 had a relatively high abundance for all irrigation treatments (Table 2). Significantly greater relative abundances of gram-positive bacteria (ANTEISO 15:0 and ISO 17:0 1G) were found in soils treated with greywater than in soils treated with harvested rain water (Table 2) and a significantly greater relative abundance of gram-positive bacteria $(16: 0)$ was found in the harvested rain water-treatments compared to all the other treatments 
TABLE 1: Input and output irrigation water chemistry. All values are $\mathrm{mg} \cdot \mathrm{L}^{-1}$. Electrical conductivity is $\mu \mathrm{S} \mathrm{cm}{ }^{-1}$. Values in parenthesis are standard deviation ( $n=20$ for input equivalent to 20 irrigation events and $n=6$ for 6 replicates per treatment inclusive of fertilized and unfertilized microcosms for outputs). HRW: harvested rain water; MTW: municipal tap water; GWB: bath greywater and GWW: washing machine greywater. Subscript I is input chemistry and Subscript $\mathrm{O}$ in output chemistry. Analyses of base cations in leachate was not performed.

\begin{tabular}{|c|c|c|c|c|c|c|c|c|}
\hline Constituent & $\mathrm{HRW}_{\mathrm{I}}$ & $\mathrm{HRW}_{\mathrm{O}}$ & $\mathrm{MTW}_{\mathrm{I}}$ & MTW $_{\mathrm{O}}$ & $\mathrm{GWB}_{\mathrm{I}}$ & $\mathrm{GWB}_{\mathrm{O}}$ & $\mathrm{GWW}_{\mathrm{I}}$ & $\mathrm{GWW}_{\mathrm{O}}$ \\
\hline $\mathrm{pH}$ & $7.92(0.36)$ & $7.90(0.06)$ & $8.44(0.10)$ & $8.67(0.02)$ & $8.81(0.45)$ & $8.68(0.06)$ & $8.64(0.46)$ & $8.59(0.06)$ \\
\hline Conductivity & $63.3(7.7)$ & $413(17)$ & $648(35)$ & $1011(51)$ & $732(181)$ & $1463(133)$ & $654(98)$ & $1362(80)$ \\
\hline $\mathrm{Na}^{+}$ & $18.7(11.6)$ & - & $205.9(24.8)$ & - & $194.9(35.2)$ & - & $189.4(30.9)$ & - \\
\hline $\mathrm{K}^{+}$ & $1.0(0.8)$ & - & $3.0(2.6)$ & - & $6.3(5.0)$ & - & $4.3(1.0)$ & - \\
\hline $\mathrm{Mg}^{2+}$ & $0.4(0.1)$ & - & $0.4(0.1)$ & - & $0.5(0.3)$ & - & $0.4(0.1)$ & - \\
\hline $\mathrm{Ca}^{2+}$ & $6.0(1.7)$ & - & $3.0(0.6)$ & - & $2.3(1.1)$ & - & $1.9(0.6)$ & - \\
\hline $\mathrm{NH}_{4}-\mathrm{N}$ & $0.07(0.09)$ & $0.14(0.02)$ & $0.03(0.02)$ & $0.16(0.03)$ & $5.6(10.5)$ & $0.41(0.05)$ & $1.6(1.2)$ & $0.18(0.02)$ \\
\hline $\mathrm{PO}_{4}-\mathrm{P}$ & $0.03(0.02)$ & $0.30(0.07)$ & $0.2(0.1)$ & $1.26(0.12)$ & $0.5(1.0)$ & $2.02(0.34)$ & $0.1(0.2)$ & $1.15(0.09)$ \\
\hline $\mathrm{NO}_{3}-\mathrm{N}$ & $0.8(0.4)$ & $2.8(0.8)$ & $0.2(0.1)$ & $4.4(0.8)$ & $0.2(0.1)$ & $17.3(3.3)$ & $0.1(0.1)$ & $6.9(0.5)$ \\
\hline $\mathrm{HCO}_{3}^{-}$ & $25.0(7.4)$ & $107.6(8.7)$ & $345.6(31.5)$ & $350.2(8.0)$ & 375.7 (93.4) & $509.0(19.2)$ & $359.4(97.5)$ & $465.9(23.6)$ \\
\hline DOC & $7.0(4.0)$ & $30.7(4.0)$ & $1.0(0.4)$ & $62.4(10.0)$ & $14.1(19.4)$ & $108.5(20.8)$ & $45.5(16.9)$ & $98.3(6.0)$ \\
\hline
\end{tabular}

(Table 2). For gram-negative bacteria, FAME biomarker $16: 1 \omega 7 \mathrm{c}$ was found in significantly higher quantities in the harvested rain water-treatment compared to all the other irrigation treatments and the relative abundance of $16: 1 \omega 5 \mathrm{c}$ was greater in the municipal tap water-treatments compared to both grey water treated soils (Figure 1). FAME biomarker CYCLO 19:0 c11-12 had a higher relative abundance in all irrigation treatments relative to the harvested rain watertreatment (Table 2). A relatively small amount of fatty acid originating from protozoa $(20: 4 \omega 6 \mathrm{c})$ was also detected in the HRW and MTW treated soils only. FAME biomarker 18:0 had a significantly higher relative abundance in GWB treated soils than in harvest rain water treated soils (Table 2).

Examining the average microbial assemblages ( $n=6$ per irrigation treatment) in our irrigated soils which may show greater consequences of the effect of irrigation water source on microbial community composition, we found that by using cluster analysis and squared Euclidean distance that the two grey water-irrigated soils were most similar in terms of microbial community composition and were very dissimilar to the soils irrigated with municipal tap water and harvested rain water (Figure 2).

3.2. Leachate Chemistry. Fertilization had no significant effect on leachate chemistry (Table 3). Leachate $\mathrm{pH}$ and conductivity were significantly different among irrigation treatments $(P<.001)$. The blank and HRW treatments had significantly lower $\mathrm{pH}$ and conductivity than the MTW, GWB, and GWW treatment leachate (Figures 3(a) and 3(c)). There was no significant difference among the MTW, GWB and GWW for $\mathrm{pH}$, but the conductivity was significantly higher in the GWB and GWW leachate compared to the HRW and MTW leachate (Figure 3(c)). Leachate dissolved organic carbon (DOC) was significantly greater from the grey water-treatments compared to the MTW and HRW treatments (Figure 3(b)). Dissolved organic nitrogen $(\mathrm{DON})$ was significantly higher in the treatments irrigated with GWB compared to the other irrigation treatments (Figure 3(d))

3.3. E. coli in Irrigation Grey Water and Leachate. At collection, approximately $50 \%$ of fresh batches of greywater collected had E. coli colony counts higher than 1000 CFU per $100 \mathrm{~mL}$. However, E. coli was not detected in leachate from treatments amended with these batches of grey water (data not shown).

\section{Discussion}

Decreasing availability of water resources for irrigating turfgrass in urban and suburban areas in the southern regions of the USA has prompted many cities to restrict or ban irrigation during the summer months. Harvesting rain water or using grey water instead of municipal tap water for irrigating landscapes are options, but their effect on soil microbial community composition and biogeochemical leaching is largely unknown. This study examined the potential effect of using alternative water sources for the irrigation of perennial ryegrass (Lolium perenne L.) on soil microbial community composition and DOC and DON leachate chemistry.

4.1. Microbial Community Composition. There is little information on the impact of grey water irrigation on the indigenous soil microbial community [9]. Surfactants may provide an easily degradable source of $\mathrm{C}$ and grey water $\mathrm{N}$ and $\mathrm{P}$ for soil microbes if soils are normally nutrient limited and, as a consequence, may stimulate microbial growth [9]. Salts and chloride on the other hand may reduce microbial functions by increasing osmotic stress [9]. We found some significant differences in the relative abundance in FAME biomarkers among soils irrigated with different watertreatments. We were interested in the effect that irrigation 
TABLE 2: Univariate analysis of variance on individual FAME biomarkers to examine the effect of irrigation source water, starter fertilizer and interactions between irrigation water and fertilizer. Bold values show a statistically significant effect at $\alpha<0.05$. + indicates an increase; - indicates a decrease and = indicates no significant increase or decrease. GWB is grey water-bath, GWW is grey water-washing machine, MTW is Municipal tap water, and ALL indicates all irrigation waters except harvested rain water.

\begin{tabular}{|c|c|c|c|c|c|c|}
\hline & Fame & $\begin{array}{l}\text { Water } \\
\text { source }\end{array}$ & Fertilizer & $\begin{array}{l}\text { Water*fertilizer } \\
\text { interaction }\end{array}$ & $\begin{array}{l}\text { Relative } \\
\text { abundanc } \\
\text { range (\%) }\end{array}$ & $\begin{array}{l}\text { Significant } \\
\text { increase or } \\
\text { decrease* }^{*}\end{array}$ \\
\hline \multirow{8}{*}{$\begin{array}{l}\text { Gram + } \\
\text { bacteria }\end{array}$} & ISO $15: 0$ & 0.68 & 0.97 & 0.12 & $4.6-4.9$ & $=$ \\
\hline & $\begin{array}{l}\text { ANTEISO } \\
15: 0\end{array}$ & 0.05 & 0.86 & 0.2 & $2.0-2.3$ & +GWB \\
\hline & $15: 0$ & 0.37 & 0.53 & 0.75 & $0-0.2$ & $=$ \\
\hline & ISO $16: 0$ & 0.56 & 0.19 & 0.19 & $2.0-2.1$ & $=$ \\
\hline & $16: 0$ & 0.00 & 0.76 & 0.42 & $17-20$ & $-\mathrm{ALL}$ \\
\hline & ISO $17: 1 \mathrm{G}$ & 0.01 & 0.78 & 0.03 & $2.9-3.5$ & +GWW \\
\hline & ISO $17: 0$ & 0.06 & 0.61 & 0.05 & $2.0-2.3$ & $=$ \\
\hline & $\begin{array}{l}\text { ANTEISO } \\
17: 0\end{array}$ & 0.25 & 0.55 & 0.96 & $0.8-1.6$ & $=$ \\
\hline \multirow{6}{*}{$\begin{array}{l}\text { Gram- } \\
\text { bacteria }\end{array}$} & $16: 1 \omega 9 c$ & 0.41 & 0.42 & 0.23 & $0-0.3$ & $=$ \\
\hline & $16: 1 \omega 7 \mathrm{c}$ & 0.00 & 0.58 & 0.04 & $3.5-4.6$ & $-\mathrm{ALL}$ \\
\hline & $16: 1 \omega 5 c$ & 0.00 & 0.04 & 0.01 & $4.9-8.3$ & $=$ \\
\hline & $\begin{array}{l}17: 0 \\
\text { CYCLO }\end{array}$ & 0.99 & 0.53 & 0.07 & $0.36-0.45$ & $=$ \\
\hline & $18: 1 \omega 5 c$ & 0.45 & 0.64 & 0.05 & $0-0.9$ & $=$ \\
\hline & $\begin{array}{l}19: 0 \\
\text { CYCLO } \\
\text { c11-12 }\end{array}$ & 0.00 & 0.32 & 0.06 & $3.8-5.7$ & $+\mathrm{ALL}$ \\
\hline \multirow{2}{*}{ Fungi } & $18: 2 \omega 6 c$ & 0.00 & 0.63 & 0.14 & $6.3-8.0$ & $-\mathrm{ALL}$ \\
\hline & $18: 1 \omega 9 c$ & 0.01 & 0.67 & 0.87 & $14.5-17.7$ & -MTW/GWB \\
\hline \multirow[t]{2}{*}{ Protozoa } & $20: 4 \omega 6 c$ & 0.13 & 0.81 & 0.95 & $0-0.4$ & $=$ \\
\hline & $17: 0$ & 0.15 & 0.06 & 0.25 & $0.4-1.2$ & $=$ \\
\hline \multirow[t]{3}{*}{ Bacteria } & $18: 0$ & 0.03 & 0.16 & 0.11 & $11.0-13.5$ & +GWB \\
\hline & $14: 0$ & 0.36 & 0.48 & 0.65 & $0.5-1.1$ & $=$ \\
\hline & $\begin{array}{l}\text { Sum in } \\
\text { feature } 8\end{array}$ & 0.07 & 0.33 & 0.11 & $9.3-10.6$ & $=$ \\
\hline \multirow[t]{5}{*}{ Other } & $\begin{array}{l}\text { 19: } 1 \\
\text { Alcohol }\end{array}$ & 0.67 & 0.96 & 0.50 & $0-0.3$ & $=$ \\
\hline & $19: 2 \omega 6 c$ & 0.94 & 0.67 & 0.10 & $0.5-0.9$ & $=$ \\
\hline & $\begin{array}{l}\text { cis } 9,10 \\
\text { epoxy } 18: 0\end{array}$ & 0.81 & 0.56 & 0.21 & $0.6-1.3$ & $=$ \\
\hline & $20: 1 \omega 9 c$ & 0.47 & 0.96 & 0.05 & $0.1-0.6$ & $=$ \\
\hline & $20: 0$ & 0.05 & 0.39 & 0.3 & $0.7-1.7$ & $=$ \\
\hline
\end{tabular}

* Significant increase or decrease is relative to soil microbes in harvested rain water-treatments at $(\alpha<0.05)$.

water source might have on soil microbial communities, and from our results, it was apparent that our municipal tap water and grey water irrigations increased some biomarkers and decreased others. Fungi and gram-negative bacteria $16: 1 \omega 7 \mathrm{c}$ had significantly higher relative abundances in harvested rain-irrigated soils compared to those soils irrigated with grey waters suggesting that the enhanced $\mathrm{pH}$, mineral, and nutrient contents of grey waters may have been responsible for the significant decline in abundance of these biomarkers. In contrast, the municipal tap and greywaterirrigated soils revealed significant increases in the relative abundance of CYCLO 19:0 c11-12 compared to the rainirrigated soils. These biomarkers are contained in gramnegative microorganisms. These proteobacteria are a major group of gram-negative bacteria which include E. coli among others suggesting that $E$. coli contributed by bath and wash water may have been retained in the soil matrix. This was an interesting result and supports the work of Hidri et al. [21] who suggested that long-term irrigation with wastewater can have an effect on the indigenous microbial structure and community composition in soils exposed to recurrent inputs of organic compounds and mineral and metallic elements. 


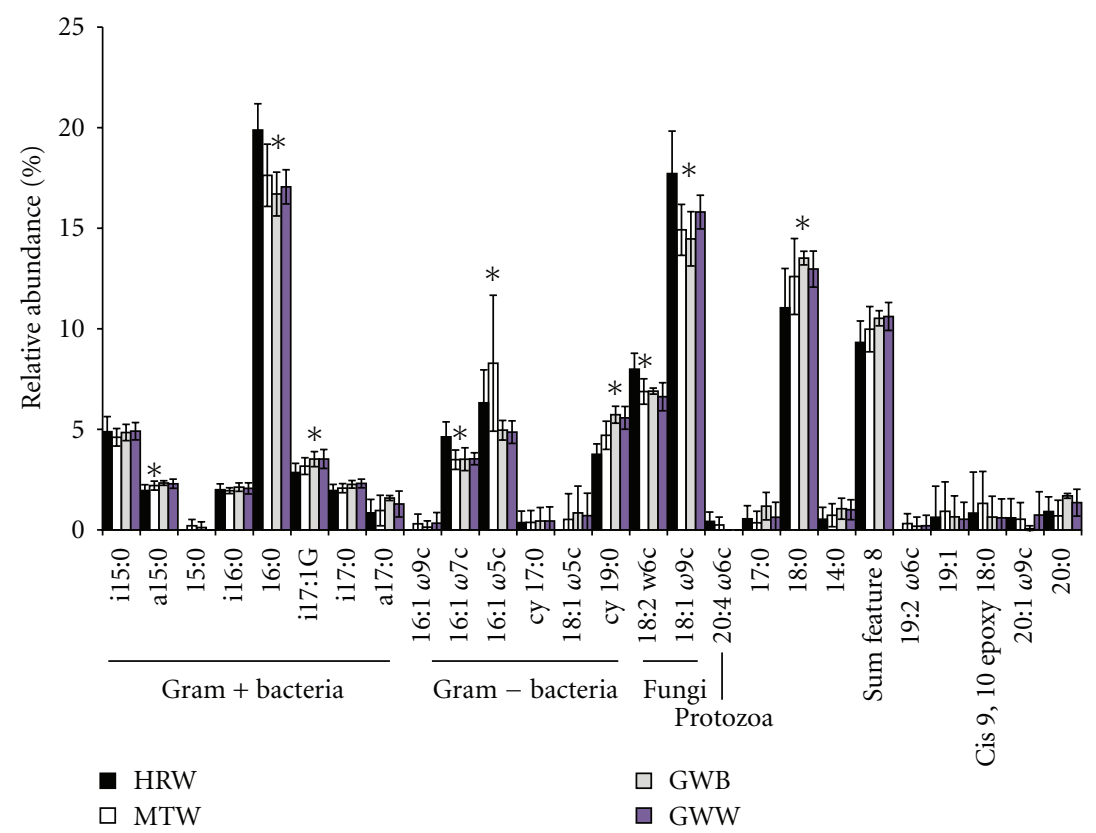

FIGURE 1: Average relative abundance for soil FAME biomarkers exposed to the irrigation treatments. Error bars are standard deviation for six replicates. ${ }^{*}$ indicates significant difference for specific FAME biomarker among irrigation treatments at $\alpha<0.05$.

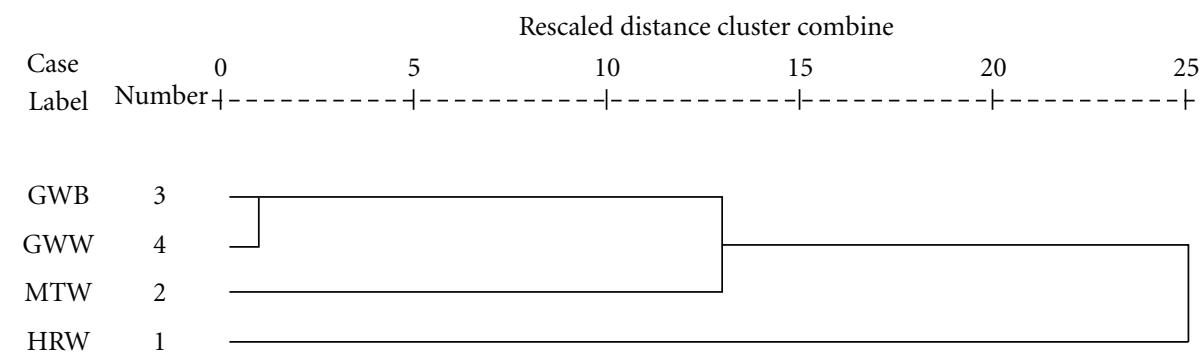

FIGURE 2: Dendogram showing similarity and dissimilarity of microbial assemblages within soils that were irrigated with different water sources. Using squared Euclidean distances, the nearer to zero the more similar the microbial community composition.

Biomarker 18:0, significantly higher in GWB than HRW soils may be attributed to stearic acid which is used for hardening soaps.

The direct effects of grey water use on soil chemistry typically include change in $\mathrm{pH}$, salinity and compounds introduced by the grey water [9]. The effect of greywater salinity will not be apparent, however, if the well or municipal tap water usually used for irrigation also has high salinity. Furthermore salinity may be an issue in homes using water softeners [9]. Several studies have investigated the effect of using treated effluent for irrigating turfgrass on soil chemistry and foliage [6,7]. Mancino and Pepper [7] used a secondary treated effluent to irrigate Bermuda grass over a 3.2-year period in Arizona, USA. They reported that the effluent water resulted in higher soil conductivity in the effluent treated plots compared to the plots irrigated with municipal tap water and suggested that this was due to the significant difference in the concentrations of sodium between irrigation effluent and municipal tap water. Sodium in their irrigation effluent ranged from $80-94 \mathrm{mg} \mathrm{L}^{-1}$ and $14-30 \mathrm{mg} \mathrm{L}^{-1}$ in their municipal tap water, much lower than the input sodium concentrations used in our study.

4.2. Dissolved Organic Carbon and Nitrogen Losses. Soils irrigated with effluent typically have higher leachate DOC lost than soils irrigated with freshwater [8]. Orchard (avocado and grapefruit) and field (cotton, corn, and sorghum) soils in the coastal plain of Israel were irrigated with freshwater and effluent [8]. Dissolved organic carbon in soil percolates ranged from 15.8 to $35.1 \mathrm{mg} \mathrm{kg}^{-1}$ for freshwater-irrigated soils and from 47.5 to $51.2 \mathrm{mg} \mathrm{kg}^{-1}$ for effluent irrigated soil over a percolation period of 3 to $4 \mathrm{~h}$ with $1 \mathrm{mM} \mathrm{CaCl}$ [8]. While the losses of DOC reported by Jueschke et al. [8] were much higher than our leaching average of $4.9 \mathrm{mg} \mathrm{kg}^{-1}$ using municipal tap water and $8.4 \mathrm{mg} \mathrm{kg}^{-1}$ from the grey 


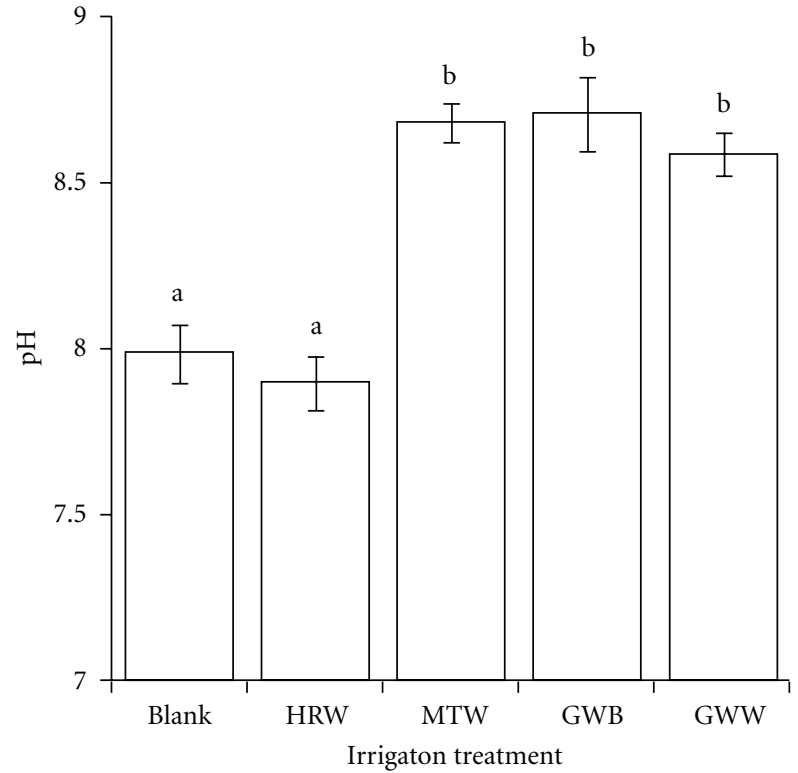

(a)

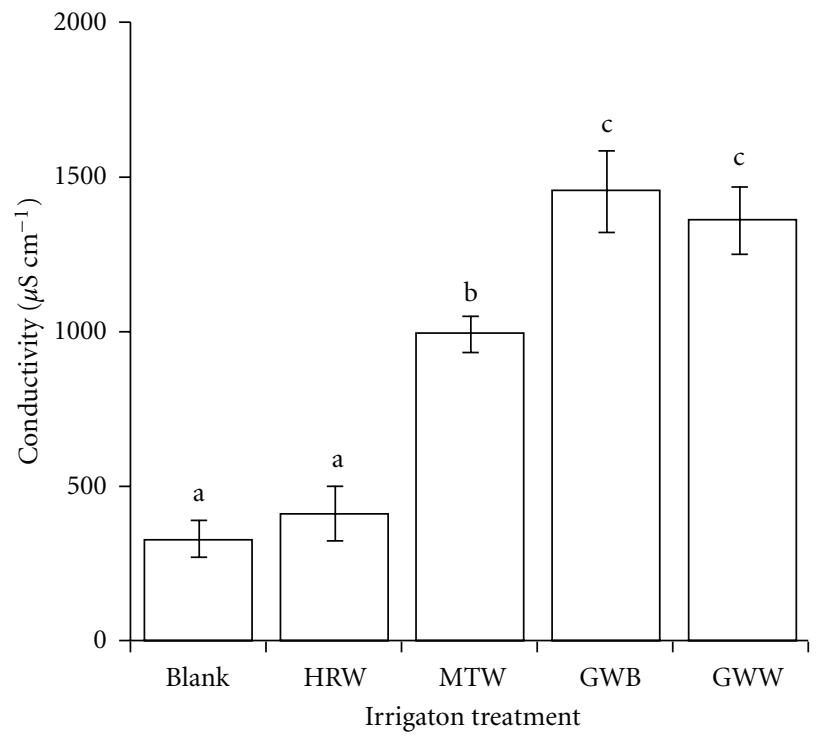

(c)

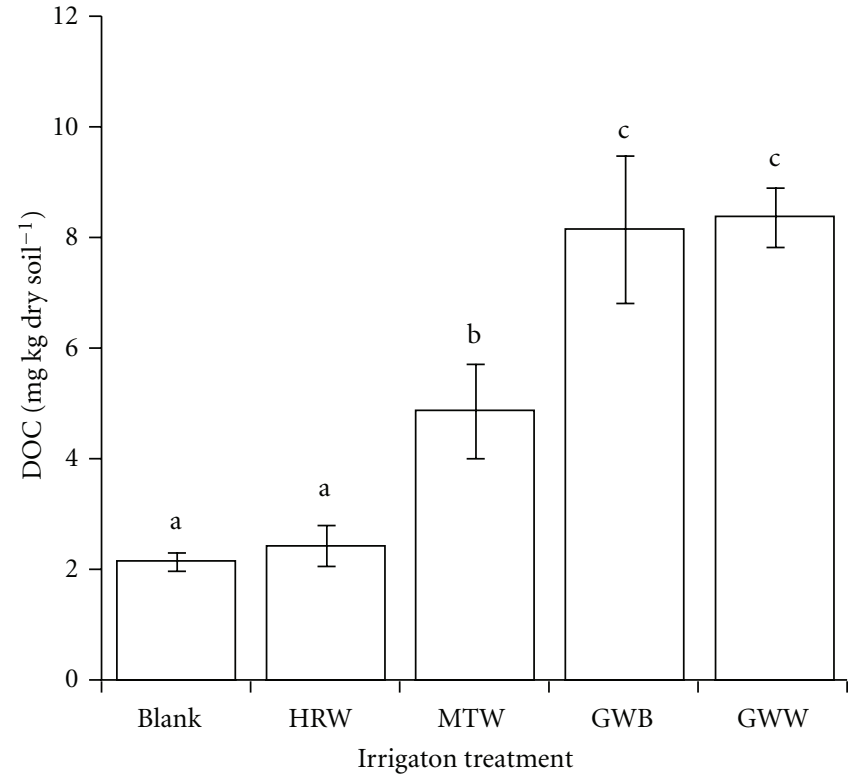

(b)

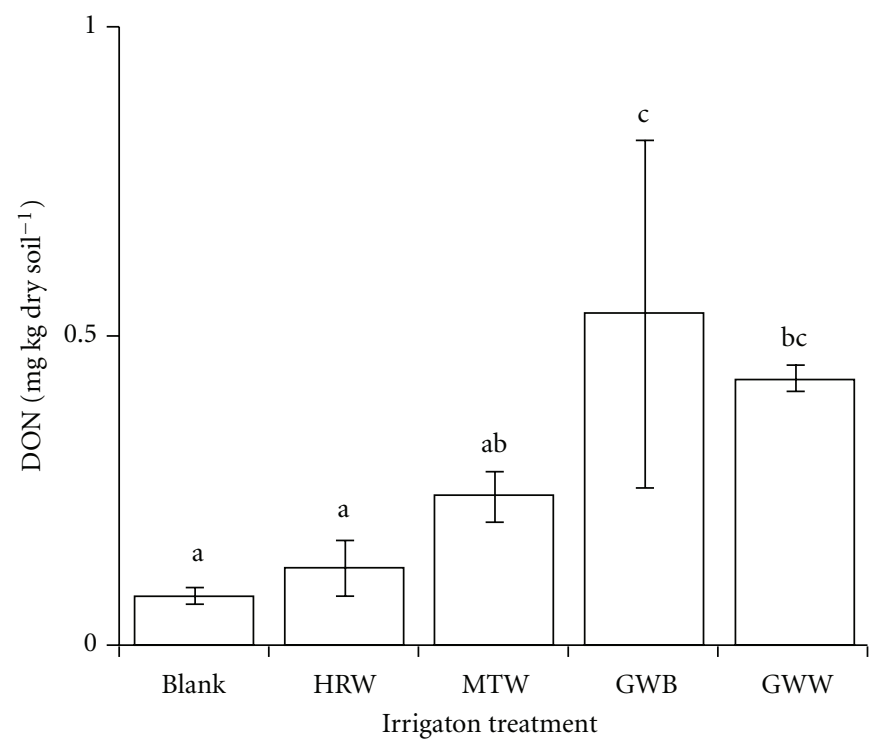

(d)

FIGURE 3: Average leachate (a) pH, (b) DOC, (c) conductivity, and (d) DON in leachate of soils irrigated with different water sources. (BLANK = soil with no turfgrass cover irrigated with harvested rain water; HRW = harvested rain water; MTW = municipal tap water; GWB = bath greywater and GWW = washing machine greywater). Error bars are the standard deviation of six treatment replicates. Differences in lower case letters indicate a significant difference among treatments at $\alpha<0.05$.

TABLE 3: Univariate analysis of variance showing the effect of irrigation, fertilizer and interaction of irrigation $\times$ fertilizer on leachate chemistry. Values in bold indicate a significant effect of treatment at $\alpha<0.05$, those not bold indicate $\alpha>0.05$.

\begin{tabular}{lcccccc}
\hline & $\mathrm{pH}$ & $\mathrm{EC}$ & $\mathrm{DOC}$ & $\mathrm{NH}_{4}-\mathrm{N}$ & $\mathrm{NO}-\mathrm{N}$ & $\mathrm{DON}$ \\
\hline Irrigation & $\mathbf{0 . 0 0 1}$ & $\mathbf{0 . 0 0 1}$ & $\mathbf{0 . 0 0 1}$ & $\mathbf{0 . 0 0 1}$ & $\mathbf{0 . 0 0 1}$ & 0.001 \\
Fertilizer & 0.64 & 0.13 & 0.96 & 0.79 & 0.49 & 0.37 \\
Fertilizer $\times$ irrigation & $\mathbf{0 . 0 3}$ & 0.39 & 0.84 & 0.68 & 0.84 \\
\hline
\end{tabular}


water-irrigated soils, both studies illustrate that the soil DOC losses from grey water or effluent irrigation is higher than from soils irrigated with municipal tap water or a fresh water source.

Effluent irrigation has been found to increase litter decomposition in other studies [22]. This effect may have been responsible for the increased DOC observed which may have been contributed from the decomposition of grass clippings that were cut and returned to the pots. Fungi are typically responsible for litter decomposition, yet our FAME markers for fungi were significantly lower in the municipal tap and grey water irrigation treatments which was likely due to increased $\mathrm{pH}$ relative to the harvested rain treatment suggesting that decomposition of the grass clippings by fungi was not the reason for enhanced DOC. However, the average temperature of $32^{\circ} \mathrm{C}$ in the green house plus additional $\mathrm{N}$ and $\mathrm{P}$ inputs from grey water may have stimulated microbial activity resulting in increased decomposition and increased production of DOC in the grey water-treatments over the period of the experiment. Temperatures of over $32^{\circ} \mathrm{C}$ are not unusual in southern states of the USA during the summer months. The contribution of $\mathrm{C}$ from surfactants may also have contributed to enhanced DOC losses. Anionic surfactants tend to adsorb less than cationic surfactants because soil tends to have a greater negative charge [9].

In a plot study investigating the effect of fertilizer and irrigation on leachate under Bermudagrass in Perth, Australia, Barton et al. [23] reported median nitrate loss to leachate of between 0.1 and $0.3 \mathrm{mg} \mathrm{L}^{-1}$, median ammonium loss of 0.1 to $0.8 \mathrm{mg} \mathrm{L}^{-1}$, and median DON losses of 0.9 to $2.9 \mathrm{mg} \mathrm{L}^{-1}$. While our average ammonium-N leachate losses were similar to those reported by Barton et al. [23], our DON losses were much higher with averages over the study period ranging from 1.5 to $7.44 \mathrm{mg} \mathrm{L}^{-1}$, the highest from the GWB treatment. The nitrogen in greywater is likely derived predominately from enzymes added to detergents, and they are expected to degrade in the soil environment contributing to soil N [9].

Our data suggests that over a 20 -week irrigation period bath water and washing machine water used as a grey water source for irrigation affected soil microbial community composition relative to soil irrigated with municipal tap water and harvested rain water. Furthermore, losses of dissolved organic carbon and nitrogen were significantly greater in grey water-irrigated soils under turfgrass. Starter fertilizer use for initiating turfgrass growth had no significant effect on microbial community composition, and it is likely that significant differences in individual FAME markers was driven by irrigation water high in sodium as was the case in our municipal tap and grey waters relative to our harvested rain water. Questions that remain to be answered include (a) what are the environmental services that individual microbes or assemblages of microbes provide? (b) How are these services impacted in urban soils in terms of biogeochemical cycling? More research needs to be conducted investigating grey water and waste water effluent affect on soil nutrient leaching and microbial community composition.

\section{Conclusions}

(i) Grey water recycling for irrigating urban and suburban turfgrass may sustain a potable water supply, but it is likely to alter the microbial community composition of soil and increase $\mathrm{C}$ and $\mathrm{N}$ biogeochemical leaching and run off likely resulting in a significant change in the environmental services that urban soils provide.

(ii) We encountered no E. coli colonies in leachates indicative of little movement through the soil profile, and this was confirmed by observation of FAMEs cy19:0 c11-12 in the greywater treated soils.

\section{Acknowledgments}

This study is a publication of Texas AgriLife Research Hatch Project TEX09194. The authors thank the Department of Soil and Crop Sciences for a graduate assistantship and the Texas Water Resource Institute Mills Scholarship awarded to L. Holgate for support with analyses. Thanks to Nina Stanley and Heidi Mjelde for help with chemical and microbial analyses.

\section{References}

[1] J. A. Aitkenhead-Peterson, M. K. Steele, N. Nahar, and K. Santhy, "Dissolved organic carbon and nitrogen in urban and rural watersheds of south-central Texas: land use and land management influences," Biogeochemistry, vol. 96, no. 1, pp. 119-129, 2009.

[2] J. A. Aitkenhead-Peterson, N. Nahar, C. L. Harclerode, and N. C. Stanley, "Chemistry of urban and rural watersheds in central Texas," Urban Ecosystems. In press.

[3] T. R. Pannkuk, R. H. White, K. Steinke, J. A. AitkenheadPeterson, D. R. Chalmers, and J. C. Thomas, "Landscape coefficients for single- and mixed-species landscapes," HortScience, vol. 45, no. 10, pp. 1529-1533, 2010.

[4] G. Oron, R. Armon, R. Mandelbaum et al., "Secondary wastewater disposal for crop irrigation with minimal risks," Water Science and Technology, vol. 43, no. 10, pp. 139-146, 2001.

[5] L. R. Parsons, B. Sheikh, R. Holden, and D. W. York, "Reclaimed water as an alternative water source for crop irrigation," HortScience, vol. 45, no. 11, pp. 1626-1629, 2010.

[6] A. R. Hayes, C. F. Mancino, and I. L. Pepper, "Irrigation of turfgrass with secondary sewage effluent .1. Soil and leachate water-quality," Agronomy Journal, vol. 82, pp. 939-943, 1990.

[7] C. F. Mancino and I. L. Pepper, "Irrigation of turfgrass with secondary sewage effluent-soil quality," Agronomy Journal, vol. 84, pp. 650-654, 1992.

[8] E. Jueschke, B. Marschner, J. Tarchitzky, and Y. Chen, "Effects of treated wastewater irrigation on the dissolved and soil organic carbon in Israeli soils," Water Science and Technology, vol. 57, no. 5, pp. 727-733, 2008.

[9] L. A. Roesner, Y. Qian, M. Criswell, M. Stomberger, and S. Klein, "Long-term effects of landscape irrigation using household graywater: literature review and synthesis," Tech. Rep. 03-CST-18C0, Water and Environment Research Foundation, Alexandria, Va, USA, 2006, http://www.werf.org/ . 
[10] P. Emrath, "Residential water use," Journal of Housing Economics, vol. 48, pp. 6-10, 2000.

[11] B. K. Ferguson, "Water conservation methods in urban landscape irrigation: an exploratory overview," Water Resources Bulletin, vol. 23, no. 1, pp. 147-152, 1987.

[12] R. S. Hilaire, M. A. Arnold, D. C. Wilkerson et al., "Efficient water use in residential urban landscapes," HortScience, vol. 43, no. 7, pp. 2081-2092, 2008.

[13] C. C. Chen, "A framework for graywater recycling of household wastewater," Polish Journal of Environmental Studies, vol. 16, no. 1, pp. 23-33, 2007.

[14] L. Hernández Leal, G. Zeeman, H. Temmink, and C. Buisman, "Characterisation and biological treatment of greywater," Water Science and Technology, vol. 56, no. 5, pp. 193-200, 2007.

[15] A. Markowicz, T. Płociniczak, and Z. Piotrowska-Seget, "Respone of bacteria to heavy metals measured as changes in FAME profiles," Polish Journal of Environmental Studies, vol. 19, pp. 957-965, 2010.

[16] L. M. Casanova, C. P. Gerba, and M. Karpiscak, "Chemical and microbial characterization of household graywater," Journal of Environmental Science and Health, Part A, vol. 36, no. 4, pp. 395-401, 2001.

[17] S. Finley, S. Barrington, and D. Lyew, "Reuse of domestic greywater for the irrigation of food crops," Water, Air, and Soil Pollution, vol. 199, no. 1-4, pp. 235-245, 2009.

[18] E. Sazakli, A. Alexopoulos, and M. Leotsinidis, "Rainwater harvesting, quality assessment and utilization in Kefalonia Island, Greece," Water Research, vol. 41, no. 9, pp. 2039-2047, 2007.

[19] M. Chang, M. W. McBroom, and R. S. Beasley, "Roofing as a source of nonpoint water pollution," Journal of Environmental Management, vol. 73, no. 4, pp. 307-315, 2004.

[20] M. A. Cavigelli, G. P. Robertson, and M. J. Klug, "Fatty acid methyl ester (FAME) profiles as measures of soil microbial community structure," Plant and Soil, vol. 170, no. 1, pp. 99113, 1995.

[21] Y. Hidri, L. Bouziri, P. A. Maron et al., "Soil DNA evidence for altered microbial diversity after long-term application of municipal wastewater," Agronomy for Sustainable Development, vol. 30, no. 2, pp. 423-431, 2010.

[22] T. G. Baker, W. J. Dyck, P. G. Barton, G. R. Oliver, and G. Nicholson, "Effect of irrigation with sewage effluent on decomposition of litter in Pinus radiata forests," Forest Ecology and Management, vol. 31, no. 4, pp. 205-214, 1990.

[23] L. Barton, G. G. Y. Wan, and T. D. Colmer, "Turfgrass (Cynodon dactylon L.) sod production on sandy soils: II. Effects of irrigation and fertiliser regimes on $\mathrm{N}$ leaching," Plant and Soil, vol. 284, no. 1-2, pp. 147-164, 2006. 

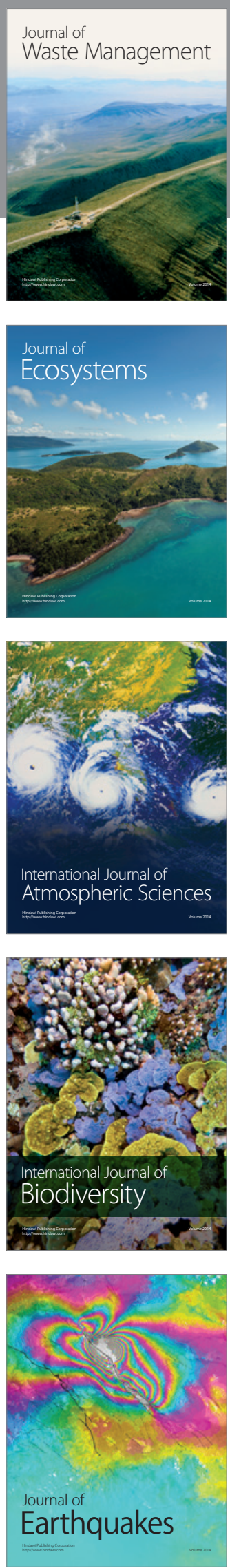
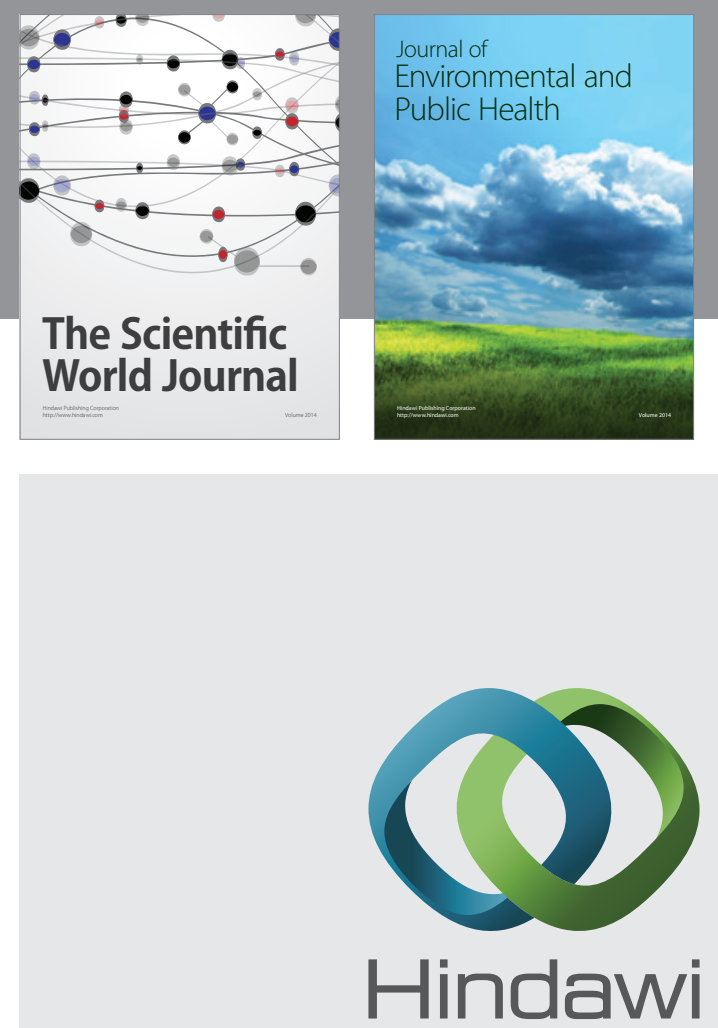

Submit your manuscripts at

http://www.hindawi.com
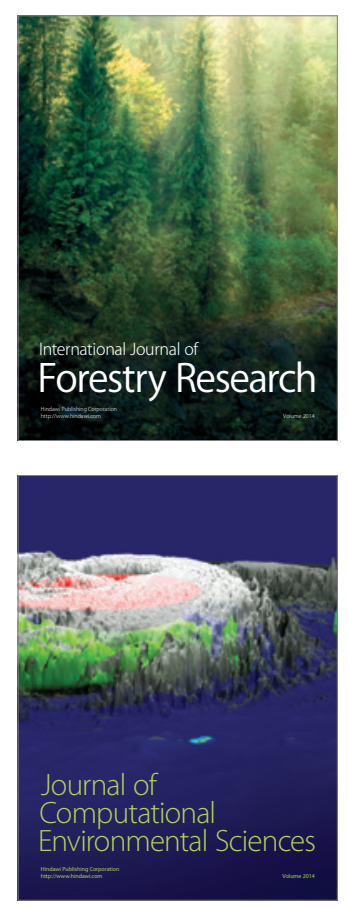
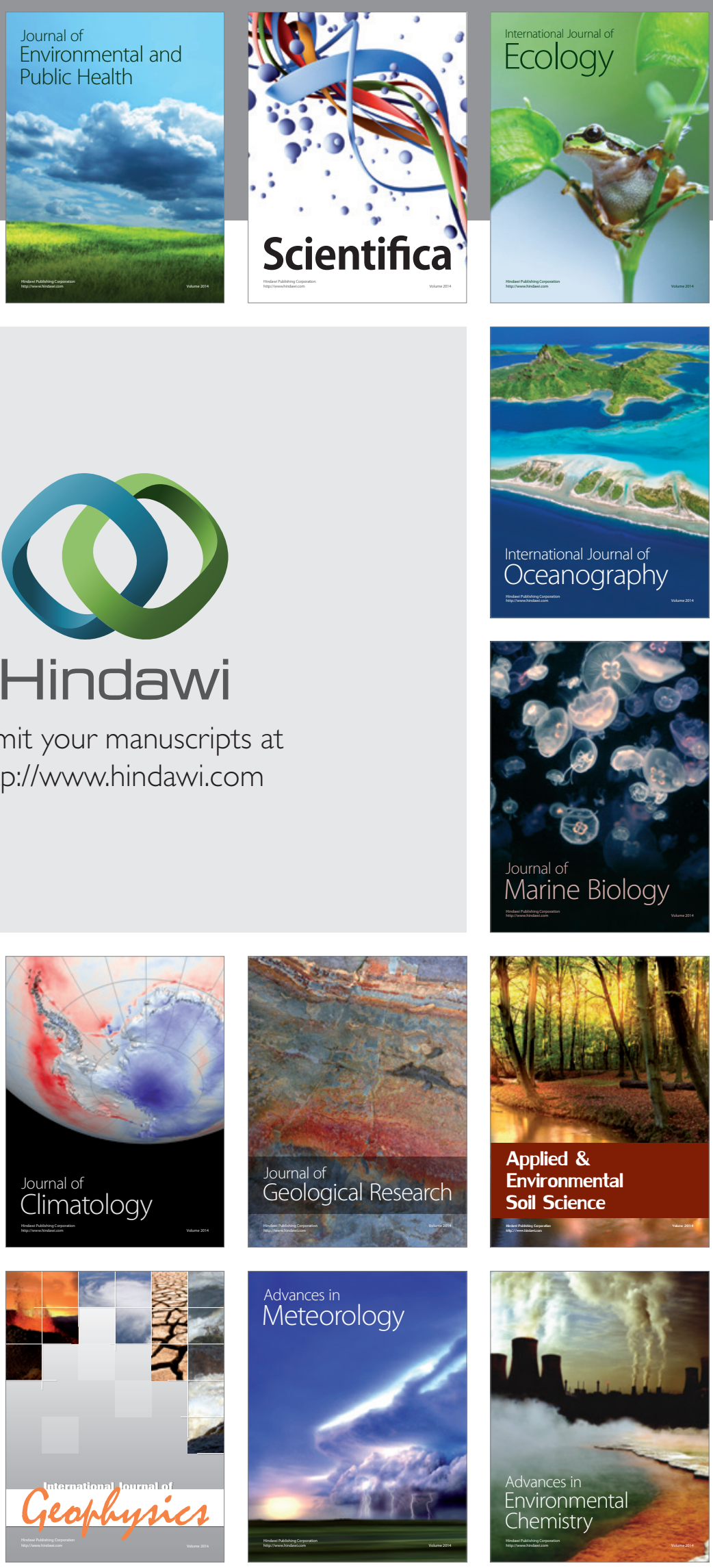